\title{
LETTERS
}

\section{Media reporting of suicide}

I congratulate Dr. Sinyor and colleagues for their excellent study on potential effects of media reports on suicide deaths, published in CMAJ. ${ }^{1}$

The article clearly outlined prospects for further research. CMAJ readers will probably be interested to know that suicidal behaviour and contagion fuelled by media reporting (Werther v. Papageno effect) are also currently being investigated in many other countries, such as Austria, Germany, China, India, the United Kingdom, Ireland and Sri Lanka. ${ }^{2-7}$

For example, in German-speaking countries, when the term "free death" (in German: Freitod) is used in the news instead of the terms "suicide" (in German: Suizid) or "self-murder" (Selbstmord), readers seem to have a greater understanding of suicide among individuals with incurable diseases. ${ }^{2}$ However, suicidal persons do not make a free, rational decision that the term "free death" supposedly implies (i.e., an emotional tunnel vision of one's own life and environment).
Unfortunately, the problematic suicide referents "free death" and "self-murder" (allegedly related to crime) are still used regularly in German-speaking countries, although the term "suicide" is recommended for media reports. ${ }^{2,8}$

I fully agree that the important findings of the study authors should be included in the development of future guidelines to the media for reporting on suicide. ${ }^{1}$ Unfortunately, most newspapers and online publications do not yet follow the principles of good media reporting of suicides, as the current data show. ${ }^{3-5,7,9}$

\section{Martin Hofmeister PhD}

Nutritional scientist, Department Food and Nutrition, Consumer Centre of the German Federal State of Bavaria, Munich, Germany

- Cite as: CMAJ 2018 December 10;190: E1458. doi: 10.1503/cmaj.70648

\section{References}

1. Sinyor M, Schaffer A, Nishikawa Y, et al. The association between suicide deaths and putatively harmful and protective factors in media reports. CMAJ 2018;190:E900-7.
2. Arendt F, Scherr S, Niederkrotenthaler T, et al. The role of language in suicide reporting: Investigating the influence of problematic suicide referents. Soc Sci Med 2018;208:165-71

3. Chu X, Zhang X, Cheng P, et al. Assessing the use of media reporting recommendations by the World Health Organization in suicide news published in the most influential media sources in China, 20032015. Int J Environ Res Public Health 2018;15:451.

4. Armstrong G, Vijayakumar L, Niederkrotenthaler T, et al. Assessing the quality of media reporting of suicide news in India against World Health Organization guidelines: a content analysis study of nine major newspapers in Tamil Nadu. Aust N Z J Psychiatry 2018;52:856-63.

5. McTernan N, Spillane A, Cully G, et al. Media reporting of suicide and adherence to media guidelines. Int J Soc Psychiatry 2018;64:536-44.

6. Marzano L, Fraser L, Scally M, et al. News coverage of suicidal behavior in the United Kingdom and the Republic of Ireland. Crisis 2018;39:386-96.

7. Brandt Sørensen J, Pearson M, Andersen MW, et al. Self-harm and suicide coverage in Sri Lankan newspapers. Crisis 2018 July 27 [Epub ahead of print]. doi: 10.1027/0227-5910/a000534.

8. Arendt F. Framing suicide - investigating the news media and public's use of the problematic suicide referents Freitod and Selbstmord in Germanspeaking countries. Crisis 2018;39:70-3.

9. Utterson M, Daoud J, Dutta R. Online media reporting of suicides: analysis of adherence to existing guidelines. BJPsych Bull 2017;41:83-6.

Competing interests: None declared. 